$104 / 24$

UC. 11

Reporting Date: Feb. 1974

Issued: June 1974

\title{
Ecological Considerations of Depleted Uranium Munitions
}

Wayne C. Hanson 
Completion report of Task 1, Project Order 4-670A-133 to Reimbursible Activities Branch, US AEC Albuquerque from USAF Armament Laboratory, Eglin AFB, FL.

Printed in the United States of America. Available from

National Technical Information Service

U.S. Department of Commerce

5285 Port Royal Ruad

Springfield, Virginia 22151

Price: Printed Copy $\$ 4.00$ Microfiche $\$ 1.45$ 


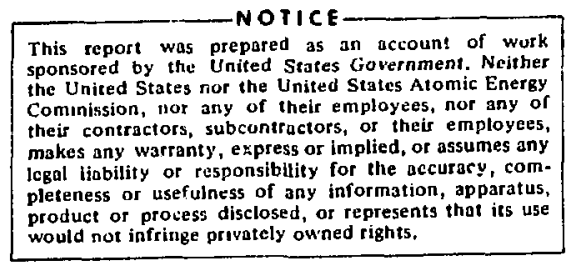

ECOLOGICAL CONSIDERATIONS OF DEPLETED URANIUM MUNITIONS

by

Wayne C. Hanson

\begin{abstract}
Ecological consequences of depleted uranium (DU) relessed to the environment as a result of milirary use of DU munitions were appraised by reviewing pertinent literature. Estimates were based upon ecosystem responses to natural uranjum, which is more soluble and more toxic than DU. It was concluded that the major ecological hazard from expended uranium munitions will be chemical toxicity rather than radiation. The alloy nature of the munitions will substantially decrease the mobility of DU and mitigate the problem. However, the ecological aspects of the chemical toxicity of DU in terrestrial ecosystems is expected to be a major consideration of expended munitions.
\end{abstract}

\section{INTRODUCTION}

This report summarizes the pertinent literature on natural and depleted uranium (DU) in the environment and synthesizes the information into an evaluation of ecological consequences of military applications of DU munitions.

Only a few environmental studies of uranium have been pursued in depth; these will form the basis for most of the projections concerning DU in the environment, about which very little is known. Extrapolating the available information to the DU situation is difficult because the munitions will be fabricated of DU alloyed with various other metals: $0.75 \%$ titanium in the Air Force type; $2 \%$ molybdenum for the Na:y type; and "Quad," composed of $0.50 \%$ titanium, $0.75 \%$ molybdenum, $0.75 \%$ zirconium, and $0.75 \%$ niobium, for the Army system. These alloys should te less subject to corrosion and less available to biotic constituents of ecosystems; therefore, conclusions regarding biological concentrations that result from natural uranium or DU in the environment will have built-in safety factors that will ameliorate the extrapolation 10 DU munitions. Discussions on uranium metallurgy, chemistry, and biology are directly applicable to either or both depleted uranium and natural uranium. Insignificant differences in the properties of natural uranium and depleted uranium, of the same purity, depend only on their differences in atomic weight. ${ }^{1}$

The studies reviewed have not been concerned with DU released to the environment in munitions because the opportunities for such studies have been limited. Definjtive investigations of $D U$ in natural environments are needed, and suggestions for such studies are included here.

\section{SOURCE TERM CONSIDERATIONS}

Most uranium ores contain 0.1 to $1 \%$ or $2 \%$ uranium expressed as $\mathrm{U}_{3} \mathrm{O}_{8}$, and average about $0.25 \%$. Of this, ${ }^{23} \mathrm{U}$ constitutes about $99 \%$ and ${ }^{235} \mathrm{U}$ about $1 \%$ uranium. Milling the ore removes about $90 \%$ of the total uranium and about $2 \%$ of the ${ }^{226} \mathrm{Ra}$, which is a major radioactive contaminant released in the tailings and other wastes. ${ }^{2}$ The refined uranium is then treated by an enrichment process at the gaseous diffusion complex of the US Atomic Energy Commission. The treatment increases the concentration of ${ }^{235} \mathrm{U}$ in a product stream of $\mathrm{UF}_{6}$ gas.

\title{
MASTER ।
}


The depleted uranium waste from the process contains about $0.2 \mathrm{wt} \%{ }^{235} \mathrm{U}$ (Ref. 1) and the remainder is ccmposed of ${ }^{238} \mathrm{U}$. The primary processing removes most of the ${ }^{238} \mathrm{U}$ decay chain products that are of principal concern, and the extremely long physica: half-life of ${ }^{238} \mathrm{U}$ $\left(4.5 \times 10^{9} \mathrm{yr}\right)$ precltides appreciable buildup of ${ }^{226} \mathrm{Ra}$ in DU during the time frame being considered.

Most of the uranium mill waste environmental studies have emphasized ${ }^{226} \mathrm{Ra}$ because of its hazara to human health, and information about ${ }^{238} U$ has been secondary. Most of the available information refers to freshwater ecosystenıs, but may be extrapolated to ocean environments by considering the differences between freshwater and ocean characteristics.

Several investigations were made at naturally radioactive areas of terrestrial environments, where thorium and/or uranium minerals in local soils and rocks provided opportunities to study the translocation of heavy radionuclides from soil to man through food chains. Other investigations showed radiation effects of natural radioactivity upon native biota, including man. Most of these studies involved aged geological deposits of radioactive elements, in contrast to our consideration of a contemporary, more insoluble form of radionuclide.

The 30-mm-diam GAU-8/A projectile contains about $300 \mathrm{~g}$ of $\mathrm{DU}$, or a radioactive inventory of $100 \mu \mathrm{Ci}$ of predominantly $4.2 \mathrm{MeV}(75 \%)$ and $4.15 \mathrm{MeV}(25 \%)$ alpha particles. These have very low penetrability $(<6 \mu \mathrm{m}$. in uranium, $\approx 33 \mu \mathrm{m}$ in water, and $2.6 \mathrm{~cm}$ in air), which is contained by the nylon or other coating during storage. Fired projectiles supposedly lose the nylon ccver, subjecting the DU to environmental weathering. This allows the DU to behave within the biogeochemical cycles with the same characteristics as natural uranium, although the alloy will retard corrosion and availability to biotic systems.

\section{DEPLETED URANIUM MUNITIONS IN TER. RESTRIAL ECOSYSTEMS}

\section{A. Wildfires During Military Exercises}

The pyrophoric properties of DU make it extremely effective in combat use where the ecological consequerices of wildfire are hardly a consideration. A similar philosophy probably exists for training purposes, although fire control is a greater concern near populated areas or where arid conditions produce flammable environments.

Fire is a most important limiting factor in ecosystems of forest and grassland regions of temperate zones and in tropical areas with dry seasons. Fire is a major hazard, and has been for centuries, of the normal climate in most of the terrestrial environments of the world. This has produced biotic, fire-adapted communities uniquely suited to a region, such as the long-leaf pine forests on the roastal plain of the southeastern United States. ${ }^{3}$ Management of controlled environments by prescribed burning has been intensively investigated in this southeastern area. Control of vegetative cover by fire is only one consideration in the total ecosystem response. Animal populations respond in various ways to such procedures, as shown in studies of wild turkey management. ${ }^{5}$ In southeastern US pine forests, controlled fire is an indispensable tool to maintain and manage turkey populations; however, it must be used wisely to ensure that associated animal populations are not jeopardized and that all populations achieve a balance. Differing responses of various species to habitat fires are found in all ecosystems, such as soil insects and their vegetative cover in desert steppe vegetation, ${ }^{6}$ caribou and their crucial lichen winter ranges in arctic areas, ${ }^{7}$ and muskrats and waterfowl in various marsh habitats. ${ }^{8,9}$ Less obvious effects of fire include the induction of mortality factors in aquatic situations. mostly due to chemical changes in the water produced :y burned vegetation. ${ }^{10}$

The above examples recognize the ecological consequences of fires caused by the pyrophoric properties of DU munitions. The degree of importance these consequences attain will depend upon the situation (wartime or training), the biog 'ographic region(s), climate. season of the year, and several other factors. Each situation must be judged independently.

\section{B. Characteristics and Consequences of Natural Uranium in Terrestrial Ecosystems}

Plants growing on uranium-vanadium deposits of the Colorado Plateau were reported to respond to the chem. ical environment in three ways. " First, controlled experiments with uranium nitrate ${ }^{12}$ showed that plant metabolism was affected by unusual amounts of uranium ore minerals available to the roots, producing anomalous growth habits. Growth was stimulated by additions of 2-ppm uranium; poisoning symptoms were noted at $\mathbf{4 7 . 6}$ ppm; acute toxicity symptoms appeared at $476 \mathrm{ppm}$; and complete toxicity to germination of seeds occurred at $1 \%$ $(=10000 \mathrm{ppm})$. Other studies ${ }^{13-15}$ show that $50-\mathrm{ppm}$ uranium in nutrient solutions causes root injury in ligher plants.

The second response is uranium. absorption, where the highest concentrations are usualiy found $\vdots$ seeds and roots, rather than leaves. Absorption is probably in. fluenced by the clay content, organic matter content, soil acidity, and the combination of available elements. Important differences in uranium absorption have been 
recorded for plant species, season of the year, anatomical part of the plant, availability of the elements in the soil, and chemical composition of the bedrock. The uranium content of any species growing in nonmineralized soil is rarely greater than $1 \mathrm{ppm}$, compared to 2 to $100 \mathrm{ppm}$ in plants rooted in uranium-bearing rock. Most of the uranium in the roots can penetrate the epidermis and then be precipitated within the root near the point of intake. which explains the localization of uranium in plant roots.

The third response of plants in high uranium areas is the development of a particular flora, or indicator species, in areas where the uranium ore body was located as much as $15 \mathrm{~m}$ underground. This must be viewed as a long-term response of plant communities to an environmental grad. ient, the most important aspect being the chemical properties of uranium. An important consideration in all plant responses is the influence of uranium upon soil microorganisms, where there was a stimulant effect at low concentrations and a toxic effect at 100 ppm. ${ }^{16}$ Generally, the detrimental effects of uranium upon soil bacteria is expected to be less than the effects upon plant cells. These principles are borne out by the results given heie.

Concentration factors (CF) for plants growing in uraniferous soils vary considerably. Cannon" reported that a wide spectrum of plants growing in mineralized soils of the Colorado Plateau contained 0.09 to 0.9 times the uranium content of shale and 0.007 to 0.01 times the uranium content of sandstone. Plants rooted in nonmineralized sandstone contained 1.25 10 1.5 times the uranium content of their substrate, even though the soils contained 20 to 100 times less uraniura than the mineralized types. Values of concentration factors between these two ranges were reported in Russia. ${ }^{17}$ where samples of soils, planis, and domestic sheep from a very broad range of environments yielded the following uranium concentratjon factors.

\begin{tabular}{|c|c|c|c|c|}
\hline \multirow[b]{2}{*}{ Component } & \multicolumn{2}{|c|}{ Control Area } & \multicolumn{2}{|c|}{ U.Rich Area } \\
\hline & $\mathrm{U}\left(\sigma^{\prime}, \mathrm{dry} w t\right)$ & $\overline{C F}$ & $\bar{U}(g, d r y$ wt $)$ & CF \\
\hline Soils & $5.0 \times 10^{5}$ & & $3.3 \times 10^{4}$ & \\
\hline Plants & $1.3 \times 10^{6}$ & 0.026 & $7.8 \times 10^{5}$ & 0.24 \\
\hline Grasses & $1.7 \times 10^{6}$ & 0.034 & $2.7 \times 10^{5}$ & 0.082 \\
\hline Slieep & $3.3 \times 10^{7}$ & 0.22 & $2.0 \times 10^{6}$ & 0.038 \\
\hline
\end{tabular}

Assuming that the daily intake of a sheep is about $2 \cdot k g$ dry matter, ${ }^{\text {B }}$ the estimated daily intake of natural uran. ium from the control area would be $0.06 \%$ of the amount required to produce a slight snalaise in sleep, and from the uranium-rich area, the intake would be $0.1 .0 .3 \%$ of the effective level. ${ }^{19}$ From the human radiologica health standpoint, it is estimated that sheep and cows must ingest daily $1-g$ and $7-g$ natural uranium, respectiveiy, for mutton or beef to achieve maximum permissible concentrations. Similarly, to give the permissible concentration in milk, the daily intake of a cow would have to be approximately 4-g natural uranium. ${ }^{20}$ Although sheep inhabiting the Russian uranium-rich areas accumulated 5 to 8 times as much uranium as the animals in the control area, no somatic changes were noted; nor would detrimental effects upon humans be anticipated from the above estimates.

Experimental evidence ${ }^{21}$ shows inat exposure levels from natural uranium-thorium terrestrial radiation can be genetically and ecologically important to highly radio. sensitive plant populations, such as Trandescantia. Demonstrable differences were reported in degree of morphological variability, the incidence of gross abnormalitics, and the rate of floral abortion in potted plants exposed to $0.25 \mathrm{mR} / \mathrm{h}$ compared to similar plants exposed to $0.10 \mathrm{mR} / \mathrm{h}$ external radiation from uranium. thorium deposits. The Russian work ${ }^{17}$ reported a 10 to $20 \%$ moiphological variability such as double nowering, leaf splitting, and corolla color variation in five plant species growing in an area where soils contained increased uranium.

The low radiation potential of DU munitions is expected to have less effect upon natural plant com. munities than on those described above. The chemical toxicity of DU, however, may be the major concern for munitions released to the environnent. This category of investigation has not yet been undertaken, although, unique opportunity to study the ecological impact of DU in terrestrial ecosystems exists at the Los Alamos Scien. tific Laboraton: High explosive weapons tests have released about 75000 - to $100000 \mathrm{~kg}$ uranium during the last $30 \mathrm{yr}$, providing opportunities to study acute and long-term impacts upon the environment.

\section{DEPLETED URANIUM MUNITIONS IN AQUATIC ECOSYSTEMS}

\section{A. Natural Urnium in Freshwater Environments}

The natural uraniun content of fresli water depends upon several factors, such as the geological formations in which waters arise and fow througl and the size and diversity of their wate:sheds. An average value for river water in the United States may be $5 \times 1 \sigma^{7} \mathrm{~g} U / \mathrm{Q}$ for rivers in environnents of igneous rocks al:d clays, and higher values may be expected in waters leaching 
carbonate rocks. ${ }^{22}$ Maximum uranium values are often near $2 \times 10^{4} \mathrm{~g} / \mathrm{l}$, which indicates a wide variance of values with a log-normal distribution. The importance of this range of values can be characterized by the report of Mallory et al. ${ }^{23}$ They estimated that, within the United States during 1960-1961 "water year," the total uranium. solute load of the Nezinscot River (Maine) was about 100 lbs, compared to 625000 lbs carried by the Mississippi River. The calculated total uranium-solute load of the rivers sampled was used to calculate that an estimated 2 million Ibs of uranium were carried in solution from the continental United States to the oceans during this "water year." In southcentral Russia, the inland Aral Sea was estimated to receive 387 tons/yr in dissolved form and 258 tons/yr as suspended material from two rivers. ${ }^{24}$ The high uranium concentrations in midwest US rivers, relative to other rivers of the world, may be explained by solubilization of the uranium in phosphate fertilizers applied to the land surface. ${ }^{25}$ The concentration of dissolved uranium in several Indian rivers ranged from 0.01 to $7.0 \mu \mathrm{g} / \mathrm{l}$, depending upon the terrain through which the river flowed. ${ }^{26}$ The total annual transport of uranium by rivers to oceans and seas was estimated to be about 20000 tons in dissolved form and an equal amount as suspended material. ${ }^{27}$

\section{B. Natural Uranium in Marine Environments}

After release into the oceans and seas, the residence time of uranium in the waters of these final runoff basins varies from tens of years to hundreds of thousands of years, depending upon the depth.

Uranium is soluble as long as the water has a high redox potential, where it exists in the hexavalent state as uranyl complex. In a reducing environment, uranium is reduced to tetravalent uranium, in which form it has a high affinity for organic material. Organic muds, black shales, and decaying organic material concentrate uranium to $350 \mathrm{ppm}$. Conversely, uranium can be held easily in solution as complex uranium tetracarbonate in high carbonate content waters, such as well-ventilated bodies of water. These oxidizing conditons, such as found in upper layers of open oceans, often contain the low uranium concentrations representing the soluble, long-lived portion of the uranium budget. Increase $s$ of uranium occur most spectacularly in the reducing environments of the occans. ${ }^{22}$ Uranium is present in sea water at concentrations of a few parts in $10^{\circ}$ (Ref. 28). It is mostly incorporated with the sediments and highly correlated with the organic matter content of such sediments. Lowest uranium values of 0.0001 to $0.0005 \%$ were reporter in sand and silty ooze along coastal areas of the inland Aral Sea and at the junction of fresh and salt waters. ${ }^{24}$ Values increased to $0.001 \%$ in sediments of the central areas of the basin. Uranium content of water around river mouths was mostly 30 to $35 \mu \mathrm{g} / \mathrm{l}$, compared to 50 to $60 \mu \mathrm{g} / \mathrm{l}$ in the central area. In the larger Black and Mediterranean Seas, average uranium concentrations of $2.0 \mu \mathrm{g} / \mathrm{l}$ were reported in sea water, ${ }^{29}$ and it was generalized that such trace metals as molybdenum, cobalt, nickel, vanadium, and carbon might be distributed in the same way as uranium in organic matter. In the Black Sea, a correlation with organic matter was more obvious for uranium and molybdenum, whereas in the Mediterranean Sea, all the metals were quite similar. Because correlation between organic matter and metals other than uranium in the surface layer of silts is absent, the observed correlation of trace metals with organic matter was explained by redistribution or recombination processes. ${ }^{30}$ The enrichment of uranium in sediments of the Baltic and Black Seas by a factor of eight over the amounts in sea water was attributed to direct and indirect action of appreciable amounts of hydrogen sulfide in those waters. ${ }^{31}$ By comparis $n$, sediments from the central Caspian Sea, which was low in $\mathrm{H}_{2} \mathrm{~S}$, contained 0.1 to 1.0 as much uranium as the Baltic and Biack Sea sejiments.

The concentration of uranium in the sediments compartment of the aquatic ecosystems is indicative of a low uranium uptake by biological systems. In humid regions of eastern Siberia, plants growing in moist soils had a range of CF's $1 \sigma^{4}$ to $10^{-1}$, with maxima in mosses. ${ }^{32}$ This $\operatorname{ran}^{2}$ ing suggests that plants growing in wet environments, having extensive surface areas, provide more accumulation sites for uranium, than an active uptake of the element. Aquatic food webs of Lake Issyk-Kul in southeastern Russia, which had a relatively high uranium concentration in water $\left(3 \times 10^{6} \%\right)$, showed a regular decrease along the route atgae-->benthic and planktonic animals - $>$ fish. Least amounts of uranium were concentrated by predatory fish, whereas most amounts were concentrated by plant-feeding species. ${ }^{33,17}$

\section{Toxicity of Uranium in Aquatic Environments}

The relative toxicity of uranium compounds is reported as follows. ${ }^{34}$

$$
\begin{array}{ll}
\mathrm{UO}_{2}, \mathrm{U}_{3} \mathrm{O}_{8}, \mathrm{UF}_{4} & : \text { Relatively non-toxic, } \\
& \text { even in large doses } \\
\mathrm{UO}_{3}, \mathrm{UCl}_{4} & : \text { Toxic in large doses } \\
\mathrm{UO}_{2}\left(\mathrm{NO}_{3}\right)_{2}, \mathrm{UO}_{4}, \mathrm{Na}_{2} \mathrm{U}_{2} \mathrm{O}_{7}: \text { Toxic in moderate doses } \\
\mathrm{UO}_{2} \mathrm{~F}_{2} & : \text { Toxic, even in relatively } \\
& \text { small doses, probably } \\
\text { due to } \mathrm{F} \text { toxicity. }
\end{array}
$$


Thus, when uranyl nitrate $\mathrm{UO}_{2}\left(\mathrm{NO}_{3}\right)_{2}$ was added to a freshwater reservoir at a uranium concentration of 1.0 $\mathrm{mg} / \mathrm{l}$, the growth of microflora was inhibited and the self-purification process $w$ as hindered. At a concentration of $100 \mathrm{mg} / \ell$, a bactericidal effect was noted. The same level of ${ }^{239} \mathbf{r} u$ radioactivity in water did not affect the growth and development of microorganisms, bacteria, or algae; therefore, it was concluded that the toxicity of the uranium resulted from its chemical action. ${ }^{35}$ Similarly, Gross and Koczy ${ }^{36}$ concluded from experiments that uranium at concentrations greater than $10^{-4} \mathrm{~g} \mathrm{U} / \mathrm{l}$ severely affected diatom survival through ionic toxicity.

\section{Anticipated Consequences of DU in Aquatic Ecosys- tems}

DU released to the environment in expended munitions will consist of the relatively nontoxic uranium compounds, which will be less soluble in water than natural uranium because of their alloy properties. The slow corrosion behavior of DU, the extremely low CF's for biota expected on the basis of data obtained from the more soluble natural uranium, ard the appreciable natural uranium load of the major water areas of the world indicate that most, if not all, of the anticipated additions of DU munitions will have little or no impact upon major water bodies.

DU deposits in small water bodies probably will involve conditions of slow dissolution of the DU but will promote its mobility and widely distribute it by natural means. A greater proportion of the uranium will be in the soluble form under such conditions, and it may be translocated physically by run-off or be biologically concentrated in small amounts.

DU munitions released to freshiwater environments in an intact condition, such as spillage during an accident, probably will remain in a relatively inert condition because of the nylon covering on the projectiles. A similar release to marine environments will free the $\mathrm{DU}$ in a much shorter time because of the corrosive nature of seawater; however, the release of DU, under the expected conditions, will not be noticed in the normal uranium background of seawater.

\section{SUMMARY AND CONCLUSIONS}

DU in various ecosystems will behave as natural uranium, but with lower solubility and without the serious consequences of ${ }^{236} \mathrm{Ra}$ that normally accompanies unrefined uranium. These characteristics provide conservative measures for comparing DU with most of the reported studies of occurrence, behavior, and effects of natural uranium in ecosystems. The principal concern will be its chemical toxicity rather than its radioactive properties.

DU released to aquatic environments is expected to have a minor impact because of low solubility and because of the appreciable amount of natural uranium normally transported by rivers from the continental landscape. This has been estimated to be 1000 tons per year from the United States and 40000 tons from all world land areas. Marsh environments may contain aquatic plants that concentrate uranium in water by factors of $10^{4}$ to $1 \sigma^{1}$; however, such concentrations are expected to occur in ecosystem components that represent a minor part of the entire consideration. Uranium is decreasingly concentrated along the aquatic food webs, with least amounts in those food chains terminating in predatory fish, such as salmon or trout. These are the major human food sources of interest, and are minimally affected from released DU.

Consequences of DU released to terrestrial ecosystems are of major importance. Considerable physical damage probably will result from wildfire caused by pyrophoric properties of DU; however, this impact is not markedly different frem other consequences of milixary operations. Increased fires will undoubtedly occur as a result of DU munitions; this will be a most important factor in ecosystems of forest and grassland regions of temperate zones and in tropical areas with dry seasons, where fire is normally a limiting factor.

The chemical toxicity of DU in terrestrial ecosystems is expected to be a major consideration of expended munitions scattered over landscapes. These situations might occur as a result of storage area explosions, transportation accidents, training exercises, or military operations. Based upon plant rommunities that colonize natural uranium ore bodies and upon controlled experiments, toxicity to uranium may occur at soil concentrations near $50 \mathrm{ppm}$ (= $50 \mu \mathrm{g} \mathrm{U} / \mathrm{g}$ soil) near the roots. and acut? toxicity symptoms may be expected in higher plants at about ten times that concentration. These should be considered as realistic guidelines until comprehensive measurements can be made of ecological consequences of DU exposed to environmental weathering for long periods of time.

\section{SUGGESTED ADDITIONAL STUDIES}

Several areas of information need further definition to describe adequately the ecological consequences of DU munitions expended in military operations. Long-term observations are needed to evaluate accurately the 
environmental impact of DU because of the gradual modified response of ecosystems to toxins that follow acute effects. Such long-term studies are required because of varying degrees of response by several ecosystem components, and because all components do not respond to the same parameter at the same time.

Several explosive testing areas within the Los Alamos Scientific Laboratory have used uranium and depleted uranium for several years (personal communication R. W. Drake to G. L. Voelz, 1971). It was estimated that 75000 - to $100000-\mathrm{kg}$ uranium were used for tests made during 1949-1970. About 35000 . to $45000-\mathrm{kg}$ ratural uranium were used during 1949-1954, and 40000 - to $55000-\mathrm{kg}$ DU were used during 1955-1970. LASL offers several areas for unique studies that have direct applications to long-term considerations of DU in natural environmental situations. It is recommended that these studies be pursued as follows.

1. Descriptive ecological studies of plant communities subjected to long-term deposition of natural and/or depleted uranium. Changes in plant communities and observation of toxicological symptoms would be a major objective.

2. Studies of natural and/or depleted uranium corrosion rates in the environments, with the objective of describing and measuring movement within the ecosystems

3. Investigations of the impact of natural and/or depleted uranium upon soil invertebrate populations.

4. Evaluation of natural and/or depleted uranium toxicity to soil microorganisms and the consequences to changes in plant communities.

5. Studies of natural and/or depleted uranium dynamics in various soil types, with the major objective of describing various corrosion rates, movement phenomena, and other relationships.

This order of studies proceeds from the general to the specific, and allows for initiating all or parts of the studies needed to describe in depth the environmental impact of DU munitions.

\section{RFFERENCES}

1. National Materials Advisory Board, "Trends in the Use of Depleted Uranium," Nat. Acad. Sci,-Nat. Res. Coun. Publ. NMAB-275 (1971).

2. E. C. Tsivoglou and R. L. O'Connell, "Nature, Volunie and Activity of Uramium Mill Wastes," in Radiological Health and Safety in Mining and Milling of Nuclear Materials, (IAEA STl/PUB/78, pp. 101-121, Vienna).

3. E. P. Odum, Fundomentals of Ecology (W. B. Saunders Conpany, Philadelphia, PA, 1971).
4. E. V. Komarek, Sr., "Lightning and Lightning Fires $A$ s Ecological Forces," in Proc. Eighth Annu. Tall Timbers Fire Ecol. Conf,, Tallahassee, FL, pp. 169-197 (1968).

5. H. L. Stoddard, Sr., "Maintenance and Increase of the Eastern Wild Turkey on Private Lands of the Coastal Plain of the Deep Southeast," Bull. Tall Timbers Res. Sta., No. 3, Tallahassee, FL (1963).

6. W. H. Rickard, "Ground Dwelling Beetles in Burned and Unburned Vegetation," J. Range Manage. 23, 293-294 (1970).

7. G. W. Scotter, "Wildfires in Relation to the Habitat of BarrenGround Caribou in the Taiga of Northern Canada," in Proc. Tenth Annu. Tall Timbers Fire Ecol. Conf., Tallahassee, FL, pp. 85-105 (1970).

S. P. Ward, "Fire in Relation to Waterfowl Habitat of the Delta Marshes," in Proc. Eighth Annu. Tall Timbers Fire Ecol. Conf., Tallahassee, FL, pp. 255-267 (1968).

9. C. J. Perkins, "Controlled Burning in the Management of Muskrats and Waterfowl in Louisiana Coastal Marshes," in Proc. Eighth Anru. Tall Timbers Fire Ecol. Conf., Tallahassee, FL, pp. 269-280 (1968).

10. C. E. Cushing, Jr., and P. A. Olson, "Effects of Weed Burning on Stream Conditions," Trans. Amer. Fish. Soc. 92, 303-305 (1963).

11. H. L. Cannon, "The Effect of Uranium-Vanadium Deposits on the Vegetation of the Colorado Plateau," Amer. J. Sci 250 , 735-770 (1952).

12. J. Stoklasa and J. Penkkava, "Biology of Uranium," Biochem. Z. 194, 15-77 (1928).

13. C. Acqua, "The Action of Uranium on the Vegetable Cell," Arch. Farmacd. Sper. 14, $81-84$ (1912).

14. C. Acqua, "Nuclear Degeneration Produced by Uranium in the Plant Cell," R. Accad. Lincei e Sci., Rendus 22, 390-392 (1913).

15. V. Bambacioni-Mezzeti, "Action of Uranium Chloride and of Gamma Rays on the Geotropical Sensibility of Roots," Soc. Ital. Progr. Sci. 22, 56-57 (1934) (in Italian).

16. G. Luchetti. "The Action of Uranium Salts on Soil Microorganisms and on Their Functions," Boll. Inst. Super. Agrar. Pisa 8,571-591 (1932).

17. V. V. Kovalsky, I. E. Vorotnitskaya, and V. S. Lekarev, "Biogeochemical Food Chains of Uranium in Aquatic and Terraneous Organisms," in Radioecological Concentration Processes, B. Aberg and F. P. Hungate, Eds. (Pergamon Press, lnc., Oxford, pp. 329-332 (1967).

18. L. K. Bustad and J. L. Terry, "Basic Anatomical, Dietary, and Physiological Data for Radiological Calculations," General Electric Company, Hanford Atomic Products Operation report HW-41638 (1956).

19. R. J. Garner, "Environmental Contamination and Grazing Animals," Health Phys. 9, 597-605 (1963).

20. R. J. Gamer, "Natural Uranium and Grazing Animals," Health Phys. 11, 323 (1965). 
21. L. W. Mericle and R. P. Mericle, "Radiation and Terrestrial Erosystems," Health Phys. 11, 1607-1620 (1965).

22. F. F. Koczy, "The Natural Radioactive Scries in Organic Material," in Radioecology. V. Schultz and A. W. Klement, Jr., Eds. (Reinhold Corporation, New York, 1963, pp. 611-613).

23. E. C. Mallory, Jr., J. O. Johnson, and R, C. Scott, "Water Load of Uranium, Radium, and Gross Beta Activity at Selected Gaging Stations, Watar Year 1960-1961," US Geological Suryey report WP-IS $35-0$ (1969).

24 A. V. Kochenoy and G. N. Baturin, "The Distribution of Uranium in the Bottom Sediments of the Aral Sea," Okeanologinya 7, 623-627 (1967) (in Russian).

25. W. M. Sackett and G. Cook, "Lranium Geochemistry of the Gulf of Mexico," Trans. Gulf Coast Assoc. Geol. Soc. 19, 233-238 (1969).

26. S. G. Bhat and S. Krishnaswamy, "Isotopes of Uranium and Radium in Indian Rivers," Proc. Indian Acad. Sci., Sec. A, 1, 1-17 (1969).

27. G. N. Baturin and A. V. Kocitenov, "Migration of Uranium in Rivers and the Duration of Its Presence in Waters of the World's Oceans, Seas, and Lakes," Geokhimiya 6, 715-723 (1969) (in Russian).

28. D. C. Stewart and W. C. Bentley, "Analysis of Uranium in Se"water," Science 120, 50-51 (1954).
29. D. S. Nikolaev, O. P. Koron, K. F. Lazarev, L. B. Kolyadin, Yu. V. Kuznetsov, and S. M. Grashehenko, "The Concentration of Uranium in the Waters of the Black Sea," Dok:l. Akad. Nauk SSSR 132, 1411-1412 (1960) (in Russian).

30. G. N. Baturin, A. V. Kochenov, and K. M. Shimkus, "Uranium and Minor Metals in Columns of Bottom Sediments of the Black and Mediterranean Seas," Geokhimiya 1, 41-50 (1967) (in Russian).

31. G. N. Baturin, "Uranium Content in Caspian Sea Sediments," At. Energy USSR 21, 516-517 (1966) (in Russian).

32. A. P. Lopatkina, V. S. Komarov, A. N. Sergeyev, and A. G. Andrcyev, "Brief Communications on Concentration of Uranium by Living and Dead Peat-Forming Plants," Engl. Trans., Geochem. Int. USSR 7, 277-282 (1970).

33. V. V. Kovalsky and I. E. Vorotnitskaya, "Regularities in the Biogenic Migration of Uranium," Uk.r. Biokhim. Zh. 38, 419-424 (1966) (in Russian).

34. A Tannenbaum and H. Silverstone, "Factors Affecting Uranium Poisoning," in Toxicalogy of Uranium, A. Tannenbaum, Ed. (McGraw-Hill, Inc., New York, pp. 11-15 1951 ).

35. V. N. Gus'kova, L. N. Gurfein, and A. I. Tikhonova, "Uranium Action in a Reservoir," Gidrobiologichesk ii Zh. 2 (6), 53-57 (1966) (in Russian).

36. F. Gross and F. F. Koczy, "Photometric Measurements of the Growth of Phytoplankton Cultures," Medd. Oceanogr. Inst. No. 10 (1946). 